\title{
Rhapontigenin Inhibited Hypoxia Inducible Factor 1 Alpha Accumulation and Angiogenesis in Hypoxic PC-3 Prostate Cancer Cells
}

\author{
Deok-Beom Jung,${ }^{a, \#}$ Hyo-Jeong LeE, ${ }^{a, \#}$ Soo-Jin Jeong, ${ }^{a}$ Hyo-Jung Lee, ${ }^{a}$ Eun-Ok LeE, ${ }^{a}$ \\ Young Chul Kim, ${ }^{a}$ Kyoo Seok AhN, ${ }^{a}$ Chang-Yan CHeN, ${ }^{b}$ and Sung-Hoon Kiм ${ }^{*, a}$ \\ ${ }^{a}$ College of Oriental Medicine, Kyung Hee University; Seoul 130-701, South Korea: and ${ }^{b}$ Beth Israel Deaconess Medical \\ Center, Harvard Medical School; Boston, MA 02215, U.S.A. \\ Received December 16, 2010; accepted February 25, 2011; published online March 7, 2011
}

\begin{abstract}
Hypoxia inducible factor 1 alpha (HIF-1 $\alpha)$ is frequently over-expressed in the numerous types of cancer and plays an important role in angiogenesis. In the present study, the inhibitory mechanism of rhapontigenin isolated from Vitis coignetiae was investigated on HIF-1 $\alpha$ stability and angiogenesis in human prostate cancer PC-3 cells. Rhapontigenin significantly suppressed HIF-1 $\alpha$ accumulation at protein level but not at mRNA level in PC-3 cells under hypoxia. Also, rhapontigenin suppressed hypoxia-induced HIF-1 $\alpha$ activation in various cancer cells, such as colorectal adenocarcinoma (SW620), breast adenocarcinoma (MCF-7), fibrosarcoma (HT-1080) and prostate carcinoma (LNCaP). Interestingly, rhapontigenin had more potency in inhibition of hypoxia-induced HIF-1 $\alpha$ expression than that of resveratrol, a known HIF-1 $\alpha$ inhibitor. In addition, rhapontigenin promoted hypoxia-induced HIF-1 $\alpha$ degradation and cycloheximide (CHX) blocked protein synthesis. A prolyl hydroxylase (PHD) inhibitor dimethyloxalylglycine (DMOG) is usually utilized to examine whether prolyl hydroxylation is involved in inhibition of HIF-1 $\alpha$ accumulation. Here, DMOG recovered HIF-1 $\alpha$ accumulation inhibited by rhapontigenin. Immunoprecipitation assay also revealed that rhapotigenin enhanced the binding of hydroxylated HIF-1 $\alpha$ to von Hippel-Lindau (VHL) tumor suppressor protein. Furthermore, rhapontigenin reduced vascular endothelial growth factor (VEGF) secretion in hypoxic PC-3 cells as well as suppressed tube formation in human umbilical vein endothelial cells (HUVECs) treated by the conditioned media of hypoxic PC-3 cells. However, antiangiogenic effect of rhapontigenin in hypoxic PC-3 cells was reversed by DMOG. Taken together, these findings suggest that rhapontigenin inhibits HIF-1 $\alpha$ accumulation and angiogenesis in PC-3 prostate cancer cells.
\end{abstract}

Key words rhapontigenin; hypoxia inducible factor 1 alpha; angiogenesis; von Hippel-Lindau protein; prostate cancer

Hypoxia inducible factor-1 (HIF-1) can be activated by hypoxic stress and plays an important role in promoting cancer angiogenesis and anaerobic metabolism. ${ }^{1)}$ HIF-1 is a heterodimeric transcription factor that consists of HIF- $1 \beta$ and HIF- $1 \alpha^{2)}$ Under normoxic condition, the alpha subunit of HIF-1 in cells is unstable because of its direct interaction with the von Hippel-Lindau (VHL) tumor suppressor protein, a component of an E3 ubiquitin ligase complex that leads to the ubiquitinization and subsequent proteasome-dependent degradation of the alpha subunit. ${ }^{3,4)}$ HIF- $1 \alpha$ mediates transcriptional activation of the promoter of vascular endothelial growth factor (VEGF), one of the most critical and specific factors that stimulate angiogenesis. ${ }^{5)}$ In general, HIF$1 \alpha$ is overexpressed in solid cancer cells ${ }^{6}{ }^{6}$ thereby up-regulating genes that favor tumor growth, metastasis, as well as induce resistance to anticancer therapies. ${ }^{7)}$ Thus, HIF- $1 \alpha$ is considered as an attractive intracellular target for treating a wide range of hypoxia-related pathologies by targeted cancer therapy. ${ }^{8)}$

Rhapontigenin (Fig. 1A) is a stilbene derivative isolated from the rhizome of Vitis coignetiae. ${ }^{9)}$ Recently, several studies showed various biological activities of rhapontigenin, such as antioxidant and antibacterial effects, ${ }^{10,11)}$ and anticancer activity. ${ }^{1213)}$ However, the inhibitory mechanism of rhapontigenin on HIF- $1 \alpha$ activation and angiogenesis in prostate cancer cells under hypoxia still remains unclear. Thus, in the present study, the molecular mechanism that rhapontigenin inhibits hypoxia-induced HIF- $1 \alpha$ activation and angiogenesis was investigated in PC-3 prostate cancer cells under hypoxia.

\section{MATERIALS AND METHODS}

Compounds Rhapontigenin and resveratrol were obtained from Korea Research Institute of Chemical Technology (Daejeon, South Korea) and SIGMA-Aldrich, respectively. The purity of both compounds is $>98 \%$ (HPLC/UV/k. max, Amersharn Pharmacia, Piseataway, NJ, U.S.A.).

Cell Culture and Hypoxia Treatment PC-3 (prostate carcinoma), SW620 (colorectal adenocarcinoma), MCF-7 (breast adenocarcinoma) and HT-1080 (fibrosarcoma) cells were purchased from the Korea cell line bank (KCLB) (Seoul, Korea). DU145 and LNCaP (prostate carcinoma) were purchased from American Type Culture Collection (ATCC) (Rockville, MD, U.S.A.). PC-3, DU145, SW620, MCF-7, HT-1080 were maintained in RPMI 1640 medium supplemented with $10 \%$ fetal bovine serum (FBS) and $1 \%$ antibiotic (WelGENE, Deagu, Korea). LNCaP were maintained in RPMI 1640 medium supplemented with $10 \%$ fetal bovine serum (FBS), $0.45 \%$ D-glucose, $10 \mathrm{~mm} N$-(2-hydroxyethyl)piperazine- $N^{\prime}$-ethanesulfonic acid (HEPES), $1 \mathrm{~mm}$ sodium pyruvate. Human umbilical vein endothelial cells (HUVECs) were isolated from fresh human umbilical cord vein by collagenase treatment as previously described, ${ }^{14)}$ which was approved by Kyung Hee Hospital IRM committee (IRB No.: KMC IRB 0910-02). The cells were cultured in M199 supplemented with 20\% heat-inactivated FBS, $3 \mathrm{ng} / \mathrm{ml}$ basic fibroblast growth factor (bFGF), 5 units $/ \mathrm{ml}$ heparin and 100 units $/ \mathrm{ml}$ antibiotic-antimycotic on $0.1 \%$ gelatin-coated flasks. HUVECs were used within passages three to six.

For hypoxia induction, cultures were incubated in a hypoxia chamber (Forma Anaerobic System, Asheville, NC, 


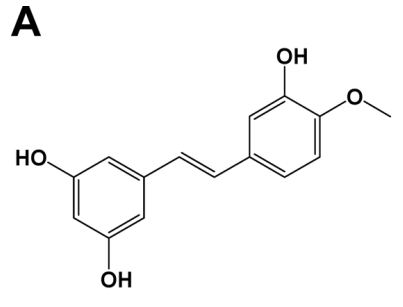

Rhapontigenin

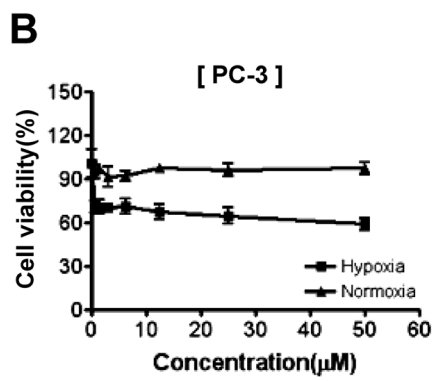

[ DU145 ]
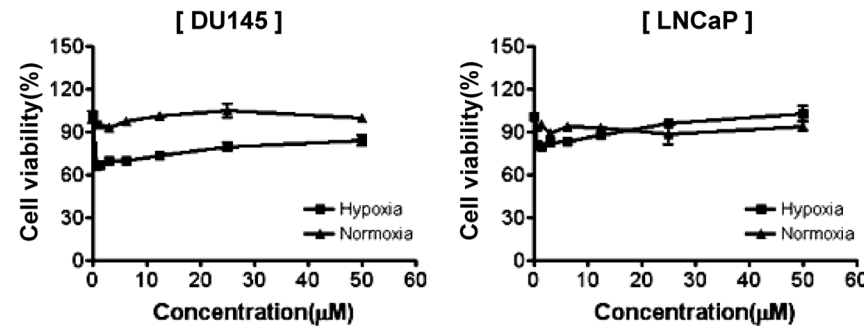

Fig. 1. Effect of Rhapontigenin on the Cytotoxicity against Prostate Cancer Cell Lines

(A) Chemical structure of rhapontigenin. Molecular weight=258.3. (B) Prostate cancer cell lines PC-3, DU145, and LNCaP cells were treated with various concentrations of rhapontigenin $(0,3.125,6.25,12.5,25$, or $50 \mu \mathrm{M})$ for $24 \mathrm{~h}$ under normoxia or hypoxia condition. Cell viability was measured by MTT assay.

U.S.A.) with a gas mixture of $94 \% \mathrm{~N}_{2} / 5 \% \mathrm{CO}_{2} / 1 \% \mathrm{O}_{2}$.

Cytotoxicity Assay To examine cytotoxic effect of rhapontigenin, 3-(4,5-dimethylthiazol-2-yl)-2,5-diphenyltetrazolium bromide (MTT) assay was performed as previously described. ${ }^{15)}$ Cells $\left(1 \times 10^{4}\right.$ cells/well) were seeded onto 96well microplates and treated with various concentrations of rhapontigenin under normoxia or hypoxia. After $24 \mathrm{~h}$ incubation, MTT solution $(5 \mathrm{mg} / \mathrm{ml})$ was added to each well for $2 \mathrm{~h}$ at $37{ }^{\circ} \mathrm{C}$ in dark and MTT extract buffer $(20 \%$ SDS and $50 \%$ dimethylformamide) was then added to each well. Optical density (OD) at $570 \mathrm{~nm}$ was measured using a microplate reader (Molecular Devices Co., Sunnyvale, CA, U.S.A.). Cell viability was calculated as a percentage of viable cells in rhapontigenin-treated group versus untreated control by following equation.

$$
\begin{aligned}
\text { cell viability }(\%)= & {[\mathrm{OD}(\text { rhapontigenin })-\mathrm{OD}(\text { blank })] / } \\
& {[\mathrm{OD}(\text { control })-\mathrm{OD}(\text { blank })] \times 100 }
\end{aligned}
$$

Western Blot Analysis Western blotting was performed as previously described. ${ }^{16)}$ Cells were lysed in radio immunoprecipitation assay (RIPA) buffer ( $50 \mathrm{~mm}$ Tris, $300 \mathrm{~mm} \mathrm{NaCl}$, $5 \mathrm{~mm}$ ethylenediaminetetraacetic acid (EDTA), and $0.5 \%$ Triton $\mathrm{X}-100)$ containing protease inhibitors $(10 \mu \mathrm{g} / \mathrm{ml}$ aprotinin, $10 \mu \mathrm{g} / \mathrm{ml}$ leupeptin, $10 \mathrm{~mm}$ iodoacetamide, $1 \%$ phenyl- methylsulfonyl fluoride (PMSF), and $10 \mu \mathrm{g} / \mathrm{ml}$ pepstatin A), and phosphatase inhibitors ( $1 \mathrm{~mm} \mathrm{NaF}$ and $1 \mathrm{~mm} \mathrm{Na} \mathrm{VO}_{4}$ ). The protein samples were quantified by using RC DC protein assay kit II (Bio-Rad, Hercules, CA, U.S.A.), separated on 6 to $15 \%$ SDS-polyacrylamide gels, and transferred to nitrocellulose membranes. The membranes were incubated with primary antibodies for HIF-1 $\alpha$ (Becton Dickinson, Bedford, MA, U.S.A.), VHL, VEGF (Santa Cruz Biotechnology, Santa Cruz, CA, U.S.A.), and $\beta$-actin (SIGMA-Aldrich, St. Louis, MO, U.S.A.), followed by incubation with a horseradish peroxisdase (HRP)-conjugated secondary antibodies. Protein expression was visualized by using enhanced chemiluminescence (ECL) Western blotting detection reagent (GE Health Care Bio-Sciences, Piscataway, NJ, U.S.A.).

Immunocytochemistry Immunocytochemical staining was manually performed at room temperature, using the avidin-biotin-peroxidase complex method (Vectastatin Elite ABC kit; Vector Labs, Burlingame, CA, U.S.A.) as described previously. ${ }^{17)}$ Cells were seeded at a density of $5 \times 10^{4}$ cells/ well in micro-slide chamber, incubated for $48 \mathrm{~h}$, and then treated either with or without rhapontigenin $(5 \mu \mathrm{M})$ for $4 \mathrm{~h}$ under hypoxia. Immunostaining for HIF-1 $\alpha$ was performed using a mouse anti-human antibody (Gene Tex, Irvine, CA, U.S.A.). The slides were counterstained with hematoxylin for 2 min before dehydration and mounting, and analyzed under a Leica microscope (Leica Microsystems Res., Wetzlar, Germany).

RNA Isolation and Reverse Transcription-Polymerase Chain Reaction (RT-PCR) RT-PCR was performed as previously described. ${ }^{17)}$ Total RNA was prepared from PC-3 cells using the Trizol reagent according to the manufacturer's instructions. Total RNA $(2 \mu \mathrm{g})$ isolated from the cells was reverse transcribed to cDNA using oligo-dT and random primers. The cDNA was amplified by PCR using the following specific primers: HIF-1 $\alpha$ : (forward: $5^{\prime}$-CTCAAAGTCGGACAGCCTCA-3'), (reverse: 5'-CCCTGCAGTAGGTTTCTGCT-3'). GAPDH: (forward: 5'-TCACCATCTTCCAGGAGCGA-3'), (reverse: 5'-CACAATGCCGAAGTGGTCGT$\left.3^{\prime}\right)$. PCR cycle for HIF- $1 \alpha$ was as follows: $95^{\circ} \mathrm{C}$ for $15 \mathrm{~min}$, $94^{\circ} \mathrm{C}$ for $45 \mathrm{~s}, 50^{\circ} \mathrm{C}$ for $45 \mathrm{~s}, 72^{\circ} \mathrm{C}$ for $1 \mathrm{~min} ; 28$ cycles, and for glyceraldehyde-3-phosphate dehydrogenase (GAPDH) was as follows: $92^{\circ} \mathrm{C}$ for $2 \mathrm{~min}, 94^{\circ} \mathrm{C}$ for $30 \mathrm{~s}, 58^{\circ} \mathrm{C}$ for $30 \mathrm{~s}, 72^{\circ} \mathrm{C}$ for $30 \mathrm{~s} ; 30$ cycles. The amplified products were separated on $1 \%$ agarose gels.

Immunoprecipitation Assay Cell extracts were incubated with anti-HIF-1 $\alpha$ antibody ( $1: 250$ dilution ratio) (Becton Dickison). The immunocomplexes were precipitated by adding $20 \mu \mathrm{l}$ of Protein A/G PLUS-Agarose Immunoprecipitation Reagent (Santa Cruz Biotechnology, Santa Cruz, CA, U.S.A.) at $4{ }^{\circ} \mathrm{C}$ for $18 \mathrm{~h}$ on a rotator, washed with lysis buffer, and subjected to Western blotting with anti-VHL antibody (Santa Cruz Biotechnology, Santa Cruz, CA, U.S.A.).

Enzyme Linked Immunosorbent Assay (ELISA) for VEGF Cell were plated onto $60-\mathrm{mm}$ tissue culture plates at a density of $5 \times 10^{5}$ cell/plate and incubated either with or without rhapontigenin $(5 \mu \mathrm{M})$ and/or dimethyloxalylglycine (DMOG) (Enzo Life Sciences Plymouth Meeting, PA, U.S.A.) under normoxia or hypoxia conditions. Culture supernatants were collected and VEGF levels in the supernatants were determined by using human VEGF ELISA kit (Biosource International Inc., Camarillo, CA, U.S.A.). 
In Vitro Tube Formation Assay In vitro tube formation assay was conducted as previously described. ${ }^{17)}$ Ice-cold matrigel (BD Bioscience) was added to coat each well of 24well plates and then polymerized by incubating for $1 \mathrm{~h}$ at $37^{\circ} \mathrm{C}$. HUVECs $\left(4 \times 10^{5}\right.$ cells $/$ well $)$ were treated with $500 \mu \mathrm{l}$ of culture supernatants from PC-3 cells treated either with or without rhapontigenin $(5 \mu \mathrm{M})$ under hypoxia in the absence or presence of VEGF $(20 \mathrm{ng} / \mathrm{ml})$. After $8 \mathrm{~h}$ incubation, randomly chosen fields were photographed under an Axiovert $\mathrm{S}$ 100 light microscope (Carl Zeiss, Weimar, Germany) at $100 \times$ magnification. Tube network was quantified using NIH Scion image program.

Statistical Analysis All data were expressed as means \pm S.D. The statistical significance was analyzed by the Student's $t$-test.

\section{RESULTS}

Effect of Rhapontigenin on the Cytotoxicity in PC-3 Cells To find examine the cytotoxic effect of rhapontigenin on various human prostate cancer cells, MTT assay was conducted after PC-3, LNCaP and DU-145 cells were treated with various concentrations of rhapontigenin for $24 \mathrm{~h}$ under normoxic or hypoxic condition (Fig. 1B). Under hypoxia condition, rhapontigenin weakly suppressed the viability of PC-3 and DU-145 cells, but had no obvious effect on LNCaP cells. Thereafter we carried out all experiments at nontoxic concentrations below $10 \mu \mathrm{M}$ to remove its cytotoxic effects.

Rhapontigenin Inhibits Hypoxia-Induced HIF-1 $\alpha$ Expression at Protein Level in PC-3 Cells HIF- $1 \alpha$ is an important factor that plays a role in response to hypoxia. ${ }^{18)}$ In our study, HIF-1 $\alpha$ was dramatically induced by hypoxia, which was peaked at $4 \mathrm{~h}$ in PC-3 cells (Fig. 2A). To investigate the effect of rhapontigenin on hypoxia-induced HIF-1 $\alpha$ protein accumulation, PC-3 cells were treated with rhapontigenin under normoxia or hypoxia condition. Rhapontigenin significantly attenuated the protein expression of HIF- $1 \alpha$ under hypoxia in a dose and time-dependent manner (Figs. $2 \mathrm{~B}, \mathrm{C}$, respectively). Consistently, immunocytochemical staining revealed rhapontigenin reduces the nuclear translocation of HIF-1 $\alpha$ compared to untreated hypoxia control (Fig. 2D).

A representative stilbene compound resveratrol (3,4'-trihydroxystilbene) was reported to inhibit HIF-1 $\alpha$ expression in various cancer cells. ${ }^{19-21)}$ Interestingly, rhapontigenin $(5 \mu \mathrm{M})$ suppressed hypoxia-mediated HIF- $1 \alpha$ expression more effectively than resveratrol $(25 \mu \mathrm{M})$ (Fig. 2E), suggesting the potential of rhapontigenin as a HIF- $1 \alpha$ inhibitor under hypoxia.

Furthermore, we evaluated whether rhapontigenin inhibits hypoxia-induced HIF-1 $\alpha$ protein accumulation in various cancer cell lines including LNCaP (androgen receptor-dependent prostate cancer cells), SW620 (colorectal cancer cells), MCF-7 (breast cancer cells) and HT-1080 (fibrosarcoma cells). Rhapontigenin attenuated hypoxia-induced HIF$1 \alpha$ protein accumulation in all cell lines tested (Fig. $2 \mathrm{~F}$ ).

Rhapontigenin Inhibits HIF-1 $\alpha$ Synthesis and Enhances the VHL Binding to HIF-1 $\alpha$ without Affecting HIF-1 $\alpha$ at mRNA Level in Hypoxic PC-3 Cells HIF- $1 \alpha$ is usually regulated not only at the protein level but also at transcription level. ${ }^{22)}$ RT-PCR analysis showed that rhapontigenin did not significantly change the HIF-1 $\alpha$ at mRNA level (Fig. 3A), while rhapontigenin downregulated HIF-1 $\alpha$
A

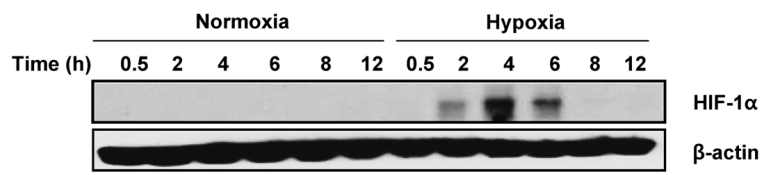

B

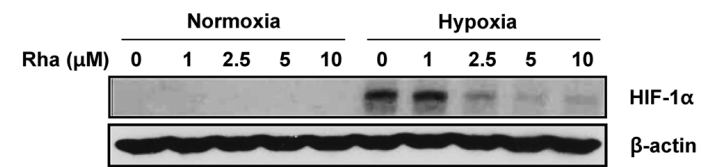

C

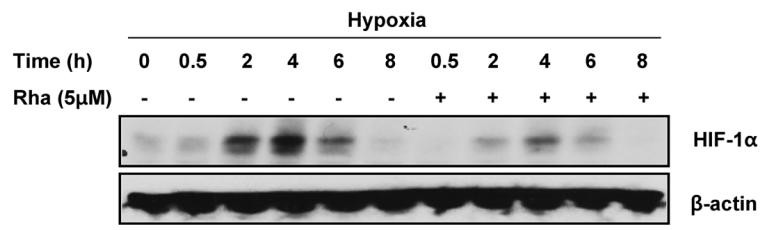

D

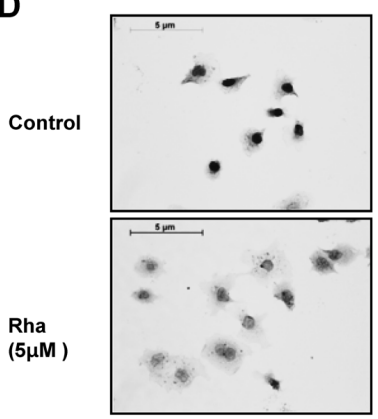

E

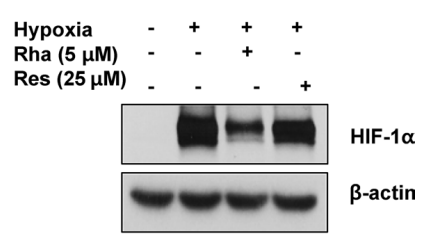

$\mathbf{F}$
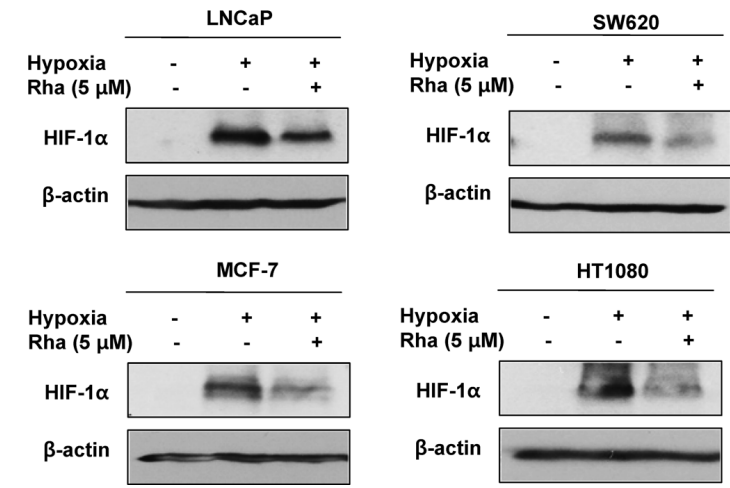

Fig. 2. Effect of Rhapontigenin on Hypoxia-Induced HIF-1 $\alpha$ Expression in PC-3 Cells

(A) Cells were exposed to normoxia or hypoxia for $0.5,2,4,6,8$, or $12 \mathrm{~h}$. (B) Cells were treated wtih various concentrations of rhapontigenin (Rha) $(0,1,2.5,5$, or $10 \mu \mathrm{M})$ for $4 \mathrm{~h}$ under normoxia or hypoxia condition. (C) Cells were treated with Rha $(5 \mu \mathrm{M})$ for $0,0.5,2,4,6$, or $8 \mathrm{~h}$ under hypoxia condition. Cell lysates were prepared and subjected to Western blotting to determine HIF-1 $\alpha$ protein expression. (D) Cells were treated with Rha $(5 \mu \mathrm{M})$ for $4 \mathrm{~h}$ under hypoxia and then analyzed for the intracellular distribution of HIF-1 $\alpha$ by immunocytochemistry. (E) Cells were treated either with or without Rha or resveratrol (Res) for $4 \mathrm{~h}$ under hypoxia condition. (F) LNCaP (androgen receptor-dependent prostate cancer), SW620 (colorectal cancer), MCF-7 (breast cancer), and HT-1080 (fibrosarcoma) cells were treated with Rha $(5 \mu \mathrm{M})$ for $4 \mathrm{~h}$ under hypoxia condition. Cell lysates were prepared and subjected to Western blotting for HIF-1 $\alpha$.

expression in PC-3 cells in a time and concentration dependent manner after exposure to hypoxia (Fig. 2). These data imply that rhaphontigenin regulates hypoxia induced HIF-1 $\alpha$ activation protein in PC-3 cells.

HIF- $1 \alpha$ hydroxylation at a specific proline is blocked under hypoxia condition, resulting in accelerating HIF-1 $\alpha$ degradation. ${ }^{23}$ To determine whether rhapontigenin treat- 
A

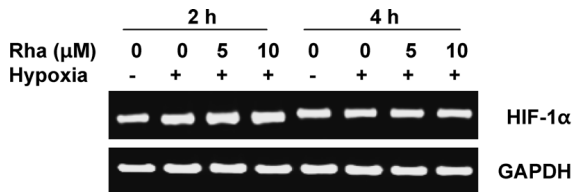

B

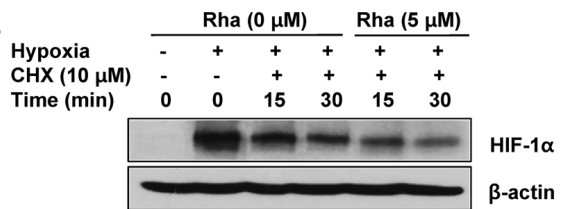

C

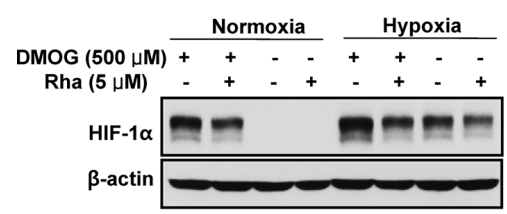

D

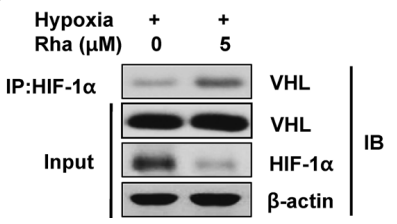

Fig. 3. Effect of Rhapontigenin on Hypoxia-Induced HIF-1 $\alpha$ Protein Stability by Post-Translational Modification in PC-3 Cells

(A) Cells were treated with various concentrations of Rha $(0,5$ or $10 \mu \mathrm{M})$ for 2 or $4 \mathrm{~h}$ under hypoxia condition. RT-PCR was performed to determine the mRNA levels of HIF-1 $\alpha$ and GAPDH. (B) Cells were incubated under hypoxia condition for $4 \mathrm{~h}$ in the absence or presence of Rha $(5 \mu \mathrm{M})$ and then treated with cycloheximide (CHX) $(10 \mu \mathrm{M})$ for 15 or $30 \mathrm{~min}$. (C) Cells were pretreated with DMOG $(500 \mu \mathrm{M})$ and treated either with or without Rha $(5 \mu \mathrm{M})$ for $4 \mathrm{~h}$ under normoxia or hypoxia condition. Cell lysates were prepared and subjected to Western blotting for HIF-1 $\alpha$. Left panel: Western blot analysis. Right panel: quantified graphs. Data represent means \pm S.D. from three independent experiments. \#p<0.001 vs. untreated control. *** $p<0.001$ vs. DMOGtreated group. $\dagger_{\dagger} p<0.01 v s$. rhapontigenin-treated group. (D) Cells were treated either with or without Rha $(5 \mu \mathrm{M})$ for $4 \mathrm{~h}$ under hypoxia condition. Cell lysates were prepared, immunoprecipitated with anti-HIF-1 $\alpha$ antibody and then immunoblotted with antiVHL antibody. Western blot analyses of the lysates (input) show the expression levels of VHL, HIF- $1 \alpha$, and $\beta$-actin.

ment affects the stability of HIF-1 $\alpha$ protein, cycloheximide (CHX), a protein translation inhibitor, was utilized to prevent de novo HIF-1 $\alpha$ protein synthesis in PC-3 cells treated either with or without rhapontigenin. The protein stability of HIF$1 \alpha$ was reduced in rhapontigenin-treated cells in comparison with untreated control (Fig. 3B), indicating that rhapontigenin accelerates the degradation process of HIF- $1 \alpha$ under hypoxia condition in PC-3 cells. Protein hydroxylation induces the proteasomal degradation of HIF- $1 \alpha$ on proline residues 402 and 564 by specific HIF-prolyl hydroxylases in the presence of iron and oxygen. ${ }^{24)}$ To test whether protein hydroxylation is involved in rhapontigenin-induced inhibition of HIF-1 $\alpha$, a prolyl hydroxylase (PHD) inhibitor DMOG was used in rhapontigenin-treated cells under normoxia and hypoxia. As shown in Fig. 3C, DMOG recovered HIF-1 $\alpha$ accumulation suppressed by rhapontigenin in PC-3 cells under normoxia and hypoxia.

The binding of HIF- $1 \alpha$ and VHL is critical to determine the half-life of HIF- $1 \alpha$ by prolyl hydroxylation. ${ }^{25)}$ In this regard, we investigated whether rhapontigenin affects the interaction of HIF- $1 \alpha$ and VHL under hypoxia. Immunoprecipita-
A

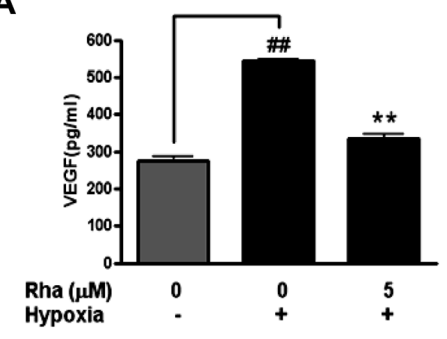

B
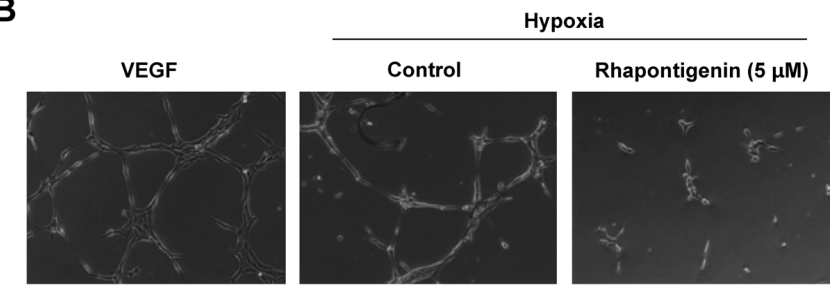

C

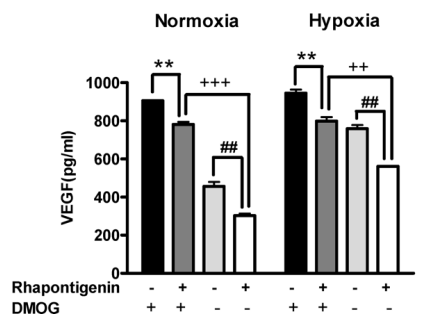

Fig. 4. Effect of Rhapontigenin on Hypoxia-Induced Angiogenesis in PC3 Cells and HUVECs

(A) Cells were treated with Rha $(5 \mu \mathrm{M})$ for $12 \mathrm{~h}$ under hypoxia condition. Secreted level of VEGF was measured by using VEGF ELISA kit. Data represent means \pm S.D. from three independent experiments. \# $p<0.01 v s$. normoxia control. $* * p<0.01 v s$. hypoxia control. (B) For in vitro tube formation, HUVECs mixed with the supernatants from PC-3 cells in the absence or presence of Rha $(5 \mu \mathrm{M})$ under hypoxia were plated onto 24-well plates coated with ice-cold Matrigel. VEGF $(20 \mathrm{ng} / \mathrm{ml})$ was used as a positive control. (C) Cells were pretreated by DMOG $(500 \mu \mathrm{M})$ with or without Rha $(5 \mu \mathrm{M})$ for $12 \mathrm{~h}$ under normoxia or hypoxia condition. DMOG significantly increased VEGF secretion in normoxia and hypoxia condition. Secreted level of VEGF was measured by using VEGF ELISA kit. Data represent means \pm S.D. from three independent experiments. \#p<0.01 vs. untreated control. $* * p<0.01$ vs. DMOG-treated group. $\pitchfork p<0.01$ and $+\dagger p<0.01 v s$. rhapontigenin-treated group.

tion assay showed that rhapontigenin enhanced the VHL binding to HIF-1 $\alpha$ in hypoxic PC-3 cells (Fig. 3D), indicating that rhapontigenin inhibits hypoxia-induced HIF- $1 \alpha$ protein stability by enhancing VHL binding to HIF- $1 \alpha$ at posttranslational level in PC-3 cells.

Anti-angiogenic Activity of Rhapontigenin Is Dependent upon Hypoxia-Mediated Prolyl Hydroxylation in PC-3 Cells Hypoxia is a strong inducer of angiogenesis through HIF-1 $\alpha{ }^{26)}$ HIF- $1 \alpha$ binds to hypoxia-response elements (HREs), thereby activating the expression of numerous hypoxia-response genes, such as the proangiogenic growth factor VEGF. ${ }^{27)}$ Thus, we measured the level of VEGF, a crucial factor of angiogenesis, by ELISA (Fig. 4A). A high level of VEGF was secreted by PC-3 cells under hypoxia in comparison with those under normoxia condition. However, rhapontigenin significantly reduced hypoxia-induced VEGF secretion in PC-3 cells under hypoxia. To further confirm anti-angiogenic effect of rhapontigenin in PC-3 cells, in vitro tube formation assay was performed in HUVECs grown on Matrigel. The cells were cultured with the conditional medium collected from PC-3 cells in the absence or presence 
of rhapontigenin under hypoxia condition. Consistent with the results of VEGF by ELISA, hypoxia-induced tube formation was blocked by rhapontigenin treatment compared to untreated hypoxia control (Fig. 4B).

To examine whether the inhibitory effect of rhapontigenin is associated with prolyl hydroxylation, VEGF levels were measured in PC-3 cells treated with rhapontigenin and/or DMOG. As shown in Fig. 4C, DMOG recovered VEGF production reduced by rhaptontigeninin PC-3 cells under normoxia and hypoxia, possibly via prolyl hydroxylation.

\section{DISCUSSION}

In the current study, the inhibitory mechanism of stilbene derivative rhapontigenin from Vitis coignetiae was evaluated on HIF- $1 \alpha$ accumulation in PC-3 cells under hypoxia. Previously, $\mathrm{Wu}$ and colleagues reported that resveratrol $\left(3,5,4^{\prime}\right.$-trihydroxy-trans-stilbene) extracted from Polygonum cuspidatum root inhibited hypoxia-induced metastasis potential by the restriction of HIF- $1 \alpha$ expression in colon carcinoma cells. ${ }^{19)}$ Zhang and colleagues ${ }^{20)}$ also reported that resveratrol inhibited hypoxia-induced accumulation of HIF-1 $\alpha$ and VEGF expression in human tongue squamous cell carcinoma and hepatoma cells. Here, we demonstrate that rhapontigenin was more effective than resveratrol in the inhibition of hypoxia-induced HIF- $1 \alpha$ activation. In addition, rhapontigenin suppressed hypoxia-induced HIF-1 $\alpha$ accumulation in various cancer cells, such as SW620, MCF-7, HT-1080 and LNCaP cells as well.

Of interest, rhapontigenin suppressed hypoxia-induced HIF- $1 \alpha$ accumulation at protein level but did not affect HIF$1 \alpha$ at mRNA level in PC-3 cells under hypoxia, implying the involvement of post-translation modification. ${ }^{28)}$ The proteasomal degradation of HIF- $1 \alpha$ occurs through protein hydroxylation on proline residues 402 and 564 by specific HIFprolyl hydroxylases in the presence of iron and oxygen. The hydroxylated protein then interacts with von Hippel-Lindau protein which functions as an E3 ubiquitin ligase. ${ }^{24,29)}$ Rhapontigenin accelerated the degradation of HIF-1 $\alpha$ in the PC-3 prostate cancer cells. Furthermore, to confirm the inhibitory effect of rhapontigenin on HIF-1 $\alpha$ accumulation via prolyl hydroxylation, the effect of PHD inhibitor dimethyloxalylglycine (DMOG) on HIF-1 $\alpha$ accumulation was evaluated in rhapontigenin-treated PC-3 cells under normoixa or hypoxia. DMOG recovered HIF-1 $\alpha$ accumulation inhibited by rhapontigenin in PC-3 cells under hypoxia, indicating the involvement of prolyl hydroxylation in inhibition of HIF- $1 \alpha$. Consistently, rhapontigenin enhanced the binding of tumor suppressor protein VHL to HIF-1 $\alpha$ in PC-3 cells under hypoxia, suggesting the possibility that HIF- $1 \alpha$ protein degradation by increasing VHL binding to $\mathrm{HIF}-1 \alpha$ protein by rhapontignein. However, further study will be required to identify the mechanism whereby rhapontigenin-mediated inhibition of HIF- $1 \alpha$ accumulation such as hydroxylation, ubiquitination, acetylation, and phosphorylation.

HIF- $1 \alpha$ plays a crucial role in cancer angiogenesis, cell proliferation, and erythropoiesis. ${ }^{30-32)}$ HIF- $1 \alpha$ activates transcription of the promoter of vascular endothelial growth factor (VEGF), a key factor in tumor angiogenesis. ${ }^{33)}$ Consequently, inhibition of VEGF secretion can be due to inactivation of HIF-1 $\alpha$ transcription, which binds to heme-respon- sive element (HRE) associated with VEGF gene. ${ }^{34,35)}$ Thus, targeting HIF- $1 \alpha$ and VEGF has been implicated to be an useful therapeutic approach for the treatment of cancer. ${ }^{36}$ ) However, although many biomedical compounds have been developed to inhibit HIF- $1 \alpha$ and VEGF, their side effects such as hypertension, bleeding and gastrointestinal perforation restrict their efficacy as therapeutic drugs. ${ }^{37)}$ Therefore, recently natural products are attractive for cancer therapy with little side effects.

Here, anti-angiogenic activity of rhapontigenin was evaluated in PC-3 cells and in HUVECs under hypoxia. Rhapontigenin decreased the secreted level of VEGF protein under hypoxia condition as well as disrupted in vitro capillary tube formation in HUVECs compared to untreated hypoxia control. Also, DMOG recovered VEGF production reduced by rhaptontigenin, suggesting the potent anti-angiogenic effect of rhapontigenin in hypoxic PC-3 cells. Overall, these findings demonstrate that rhapontigenin inhibits HIF-1 $\alpha$ accumulation as well as angiogenesis in hypoxic $\mathrm{PC}-3$ prostate cancer cells. However, it is also required to confirm the mechanism of rhapontigenin as a HIF- $1 \alpha$ inhibitor in animal study.

Acknowledgement The present study was supported by the Korea Science and Engineering Foundation (KOSEF) grant funded by the Korea government (MEST) (No. 20110063466).

\section{REFERENCES}

1) Dewhirst M. W., Cao Y., Moeller B., Nat. Rev. Cancer, 8, 425-437 (2008).

2) Bertout J. A., Patel S. A., Simon M. C., Nat. Rev. Cancer, 8, 967—975 (2008).

3) Kaelin W. G. Jr., Nat. Rev. Cancer, 8, 865-873 (2008).

4) Ji Q., Burk R. D., Biochem. Cell Biol., 86, 227-234 (2008).

5) Ferrara N., Gerber H. P., LeCouter J., Nat. Med., 9, 669-676 (2003).

6) Zhong H., De Marzo A. M., Laughner E., Lim M., Hilton D. A., Zagzag D., Buechler P., Isaacs W. B., Semenza G. L., Simons J. W., Cancer Res., 59, 5830-5835 (1999).

7) Park J. W., Chun Y. S., Kim M. S., J. Pharmacol. Sci., 94, 221-232 (2004).

8) Semenza G. L., Genes Dev., 14, 1983-1991 (2000).

9) Roupe K. A., Remsberg C. M., Yañez J. A., Davies N. M., Curr. Clin. Pharmacol., 1, 81-101 (2006).

10) Zhang R., Kang K. A., Piao M. J., Lee K. H., Jang H. S., Park M. J., Kim B. J., Kim J. S., Kim Y. S., Ryu S. Y., Hyun J. W., J. Toxicol. Environ. Health A, 70, 1155-1166 (2007).

11) Kim J. K., Kim N., Lim Y. H., J. Microbiol. Biotechnol., 20, 82-87 (2010).

12) Chun Y. J., Ryu S. Y., Jeong T. C., Kim M. Y., Drug Metab. Dispos., 29, 389-393 (2001).

13) Roupe K. A., Helms G. L., Halls S. C., Yañez J. A., Davies N. M., J. Pharm. Pharm. Sci., 8, 374-386 (2005).

14) Jaffe E. A., Nachman R. L., Becker C. G., Minick C. R., J. Clin. Invest., 52, 2745-2756 (1973).

15) Won S. H., Lee H. J., Jeong S. J., Lee H. J., Lee E. O., Jung D. B., Shin J. M., Kwon T. R., Yun S. M., Lee M. H., Choi S. H., Lu J., Kim S. H., Biol. Pharm. Bull., 33, 1828-1834 (2010).

16) Ahn Q., Jeong S. J., Lee H. J., Kwon H. Y., Han I., Kim H. S., Lee H. J., Lee E. O., Ahn K. S., Jung M. H., Zhu S., Chen C. Y., Kim S. H., Cancer Lett., 298, 212-221 (2010).

17) Park K. Y., Lee H. J., Jeong S. J., Lee H. J., Kim H. S., Kim S. H., Lim S., Kim H. C., Lü J., Kim S. H., Biol. Pharm. Bull., 33, 1835-1840 (2010).

18) Wang G. L., Semenza G. L., J. Biol. Chem., 270, 1230-1237 (1995).

19) Wu H., Liang X., Fang Y., Qin X., Zhang Y., Liu J., Biomed. Pharma- 
cother, 62, 613-621 (2008).

20) Zhang Q., Tang X., Lu Q. Y., Zhang Z. F., Brown J., Le A. D., Mol. Cancer Ther, 4, 1465-1474 (2005).

21) Cao Z., Fang J., Xia C., Shi X., Jiang B. H., Clin. Cancer Res., 10, 5253-5263 (2004).

22) McNeill L. A., Hewitson K. S., Claridge T. D., Seibel J. F., Horsfall L. E., Schofield C. J., Biochem. J., 367, 571-575 (2002).

23) Bedard K., Krause K. H., Physiol. Rev., 87, 245-313 (2007).

24) Lee C. H., Jeong S. J., Yun S. M., Kim J. H., Lee H. J., Ahn K. S., Won S. H., Kim H. S., Lee H. J., Ahn K. S., Zhu S., Chen C. Y., Kim S. H., Proteome Sci., 8, 67 (2010).

25) Yu F., White S. B., Zhao Q., Lee F. S., Proc. Natl. Acad. Sci. U.S.A., 98, 9630-9635 (2001).

26) Zhang J., Li L., Kim S. H., Hagerman A. E., Lü J., Pharm. Res., 26, 2066-2080 (2009).

27) Harris A. L., Nat. Rev. Cancer, 2, 38-47 (2002).

28) Huang L. E., Gu J., Schau M., Bunn H. F., Proc. Natl. Acad. Sci. U.S.A., 95, 7987-7992 (1998).
29) Maxwell P. H., Semin. Cell Dev. Biol., 16, 523-530 (2005).

30) Mirzoeva S., Kim N. D., Chiu K., Franzen C. A., Bergan R. C., Pelling J. C., Mol. Carcinog., 47, 686-700 (2008).

31) Schoppmann S. F., Fenzl A., Schindl M., Bachleitner-Hofmann T., Nagy K., Gnant M., Horvat R., Jakesz R., Birner P., Breast Cancer Res. Treat., 99, 135-141 (2006).

32) Song Y., Wang W., Qu X., Sun S., Indian J. Med. Res., 129, 154-163 (2009).

33) Jung J. E., Lee H. G., Cho I. H., Chung D. H., Yoon S. H., Yang Y. M., Lee J. W., Choi S., Park J. W., Ye S. K., Chung M. H., FASEB J., 19, 1296-1298 (2005).

34) Shankar J., Thippegowda P. B., Kanum S. A., Biochem. Biophys. Res. Coтmun., 387, 223-228 (2009).

35) Yao H., Wang H., Zhang Z., Jiang B. H., Luo J., Shi X., Int. J. Cancer, 123, 1255-1261 (2008)

36) Semenza G. L., Nat. Rev. Cancer, 3, 721-732 (2003).

37) Kamba T., McDonald D. M., Br. J. Cancer, 96, 1788-1795 (2007). 